\title{
Ecological Assessment of a Marine Coastal Area Affected by a Power Plant Water Discharge (Brindisi, Adriatic Sea)
}

\author{
Gabriele Matteucci ${ }^{1}{ }^{*}$, Mirko Magagnini ${ }^{2}$, Monica Armeni ${ }^{2}$, Luca Giaccaglia ${ }^{2}$, Federica \\ Fiesoletti ${ }^{1}$, Claudia Ciotti ${ }^{2}$, Patrizia Pari ${ }^{1}$, Sandro Riccio ${ }^{1}$, Paolo Rossini ${ }^{1}$, Paolo Ambrosini ${ }^{3}$, \\ Euro Buongarzone ${ }^{3}$, Leonardo Patata ${ }^{3}$, Luigi Trovarelli ${ }^{3}$ and Pierpaolo Tentoni ${ }^{1}$ \\ ${ }^{I}$ Istituto di Ricerca Gruppo CSA S.p.A., Rimini, Italy \\ ${ }^{2}$ EcoTechSystems s.r.l, Ancona, Italy \\ ${ }^{3}$ SAIPEM S.p.A., Fano, Italy
}

\begin{abstract}
Coastal ecosystems are subjected to multiple stresses, from physical disturbance to chemical contamination related to the local anthropogenic activities. The recent European directives and Italian laws recommend that the assessment of the ecological quality of costal seawater should be based on an integrated approach, taking into account the ecological complexity of the systems and highlighting the potential sources of impact. Here, we present the results of an environmental study carried out in the marine coastal area affected by the sea discharge of a Combined Cycle Power Plant (Torre Cavallo, Brindisi) and characterized by the presence of a Posidonia oceanica meadow. The study focused on the concentration of chemical contaminants in sediments, coupled with the study of quali-quantitative determinations of biological benthic communities meio- and macrozoobenthos). Data were integrated with data of phenology and lepidochronology of $P$. oceanica, as well as the concentrations of trace elements in leaves and rhizomes, in order to identify potential sources of stress. Results suggested a good status of health of the coastal marine ecosystem.
\end{abstract}

Keywords: Posidonia oceanica, heavy metals, bioaccumulation, biodiversity.

\section{INTRODUCTION}

Coastal ecosystems are typically subjected to multiple simultaneous threats, as a direct result of their high vulnerability. For this reason, the reaching of a high standard in terms of environmental quality of marine coastal areas has become one of the priorities in EC environmental legislation, as reported in the Water Framework Directive 2000/60/UE (WFD) and the related national laws in matters of the environment (as the Italian law $\mathrm{n}^{\circ} 152 / 2006$ and subsequent integrations). The reaching of high environmental quality implies the monitoring of marine coastal areas, in particular in regions where the presence of industrial plants could have a negative impact on key ecosystems, as seagrass meadows. Posidonia oceanica (L.) meadows are defined as priority habitats on Annex I of the EC Directive 92/43/EEC on the Conservation of Natural Habitats and Wild Fauna and Flora (EEC 1992).

In particular, $P$. oceanica meadows represent important ecosystems particularly subjected to changes in environmental quality $[1,2]$. $P$. oceanica, the dominant seagrass in the Mediterranean Sea, is an endemic species that may form extensive meadows down to $40 \mathrm{~m}$. These meadows constitute one of the most productive and valuable ecosystems in the Mediterranean Sea [3, 4]. Despite being listed as a protected species in the Habitats Directive (EC, 1992),

*Address correspondence to this author at the Istituto di Ricerca Gruppo CSA S.p.A., Rimini, Italy; Tel: +390541791050; Fax: +390541791045;

E-mail: gmatteucci@csaricerche.com
P. oceanica habitats are experiencing a widespread decline [5]. These losses are commonly attributed to human activities such as bottom-trawl fishing, coastal constructions, beach nourishment, fish farming and desalination plants [6-10]. Given its broad distribution throughout the Mediterranean Sea and its sensitivity, $P$. oceanica might be used as an appropriate bio-indicator [11] and has been proposed as one of the biological quality elements for coastal waters in the EUWFD [12].

The wide spectrum of possible threats for marine ecosystems in anthropized areas implies the use of an integrated monitoring approach, which takes into account the different classes, sources and effects of the potential pollution. For this reason, the environmental quality of marine coastal areas is currently defined through multidisciplinary studies, in which the study of key biological variables, such as meiobenthos and macrozoobenthos, is supported by physicochemical and chemical data of water column and sediments [13].

Here, we present the results of a multidisciplinary study performed on seawater, sediments and biota of a $P$. oceanica meadow subjected to the effects of the sea discharge of a Combined Cycle Power Plant. The quali-quantitative analyses of benthic communities, as well as phenological and lepidochronological data of $P$. oceanica, were integrated with physico-chemical and chemical data of both seawater and sediments, providing a useful description of the health status of the meadow. 


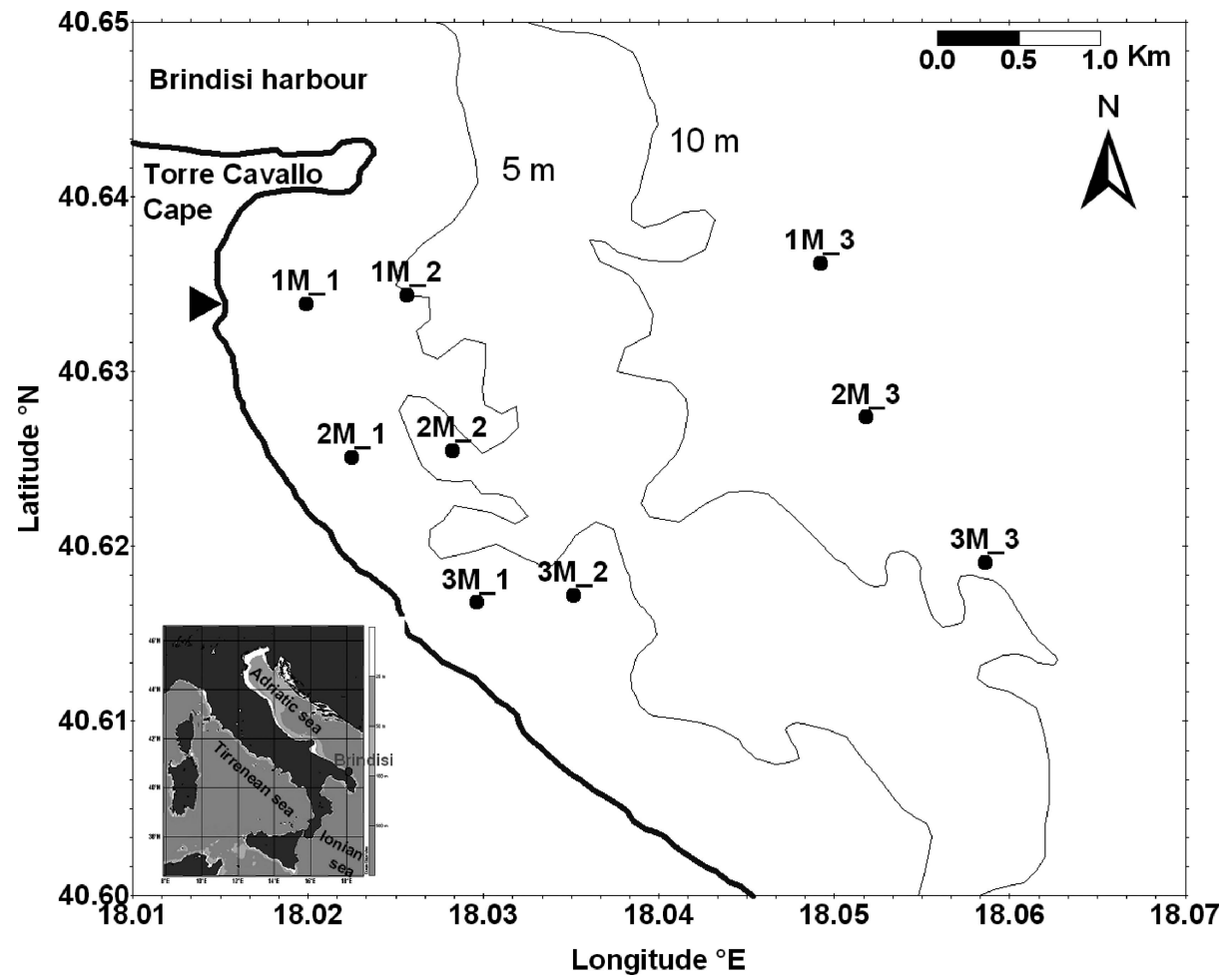

Fig. (1). Study area and sampling strategy. $\$$ : discharge of the Power Plant.

\section{MATERIALS AND METHODOLOGY}

\section{Study Site and Sampling Strategy}

The study site is the coastal marine area of Torre Cavallo, Brindisi, Southern Italy. The area is limited by Torre Cavallo Cape (North) and "Salina Punta della Contessa" (South). Sampling grid was planned to monitor the Combined Cycle Power Plant cooling system water discharge into the coastal area. Samples of seawater and sediments were collected at 9 stations placed on 3 coast-orthogonal transects, according to the Italian law 152/06 and Environmental Ministry (ICRAM) Protocols [14]. The transects were $1000 \mathrm{~m}$ apart from each other (Fig. 1). On each transect, 3 stations were investigated (located at 500, 1000 and $3000 \mathrm{~m}$ from the coast, respectively M1, M2, M3). At each station, a synoptical acquisition of physico-chemical, chemical and biological data was performed. Sampling was performed in June 2009 and in November 2009.

\section{Determinations of Hydrological Variables in Seawater}

Measurements of the main chemical and physical parameters in the water column were performed according to ICRAM [14]. A self acquiring real-time multi-probe (SBE 19 Plus Seacat Profiler) was used for the acquisition of vertical profiles of conductivity, temperature, pressure, $\mathrm{pH}$ and dissolved oxygen. Salinity and depth were calculated by suitable data processing software, following the UNESCO international procedures [15]. All measurements were carried out continuously from the sea surface to the bottom.

\section{Determinations of Chemical Variables in Seawater}

Water samples for chemical and biological analyses were collected by means of a "Niskin type" hydrological bottle, according to ICRAM protocols [14]. Samples were collected on surface waters and in bottom water layer. Each sample was stored in appropriate containers accordingly to ICRAM protocols [14].

Chlorophyll a. After collection, samples for the determination of chlophyll $a$ concentrations were immediately filtered onto $\mathrm{GF} / \mathrm{F}$ filters and stored at $-20^{\circ} \mathrm{C}$ for the laboratory analyses [14].

Nutrients. Immediately after recovery, water samples for the determinations of inorganic nutrients (total nitrogen, nitrate, nitrite, ammonia, orthophosphate and total phosphorous) were filtered through a cellulose acetate filter (porosity $0.45 \mu \mathrm{m}$ ). Samples were stored in polyethylene containers, previously rinsed twice with the filtered water, and stored at $-20{ }^{\circ} \mathrm{C}$ until analyses [14].

\section{Determinations of Physico-Chemical and Chemical Variables in Sediments}

At each station, a Van Veen grab was used to collect sediment samples for the determination of physico-chemical, chemical and biological variables. In order to minimize the potential contamination, the sampling equipment was washed before deployment at each sampling point.

The surface sediments (first $2 \mathrm{~cm}$ ) resulting from the grab were homogenized, transferred into HDPE containers and stored at $-20^{\circ} \mathrm{C}$ for the laboratory determinations of the following variables:

Grain size. Sub-aliquots of surface sediments $(0-2 \mathrm{~cm}$ layer) were analyzed with sieves and Sedigraph III 5120 to determine in detail different fractions.

Total Organic Carbon (TOC). Sub-aliquots of surface sediments $(0-2 \mathrm{~cm}$ layer) were treated according to ICRAM protocols [14] for TOC analysis. TOC concentrations were determined by a CHNS-analyzer. 
Heavy metals. Sub-aliquots of surface sediments $(0-2 \mathrm{~cm}$ layer) were totally dissolved by means of acid digestion and analyzed by ICP-AES for metal determinations (Al, As, Cd, Total $\mathrm{Cr}, \mathrm{Cu}, \mathrm{Fe}, \mathrm{Pb}, \mathrm{Zn}$ ).

\section{Determinations of Chemical Variables in Tissues of Posidonia Oceanica}

The concentrations of chemical contaminants were investigated in leaves and rhizomes of Posidonia oceanica. Samples collected by SCUBA divers in all the 9 investigated stations were stored at $-20^{\circ} \mathrm{C}$ until laboratory analyses. In both matrices, metals ( $\mathrm{Al}, \mathrm{As}, \mathrm{Cd}$, Total $\mathrm{Cr}, \mathrm{Cu}, \mathrm{Fe}, \mathrm{Pb}, \mathrm{Zn}$ ) were determined by ICP-AES as described in [11].

\section{Quali-Quantitative Determinations of Meio- and Macrozoobenthos}

The quali-quantitative analyses of meiobenthos were performed on three replicate samples collected at each sampling station. Sediment cores (surface $10 \mathrm{~cm}^{2}$ ) were collected by subsampling three independent Van Veen grab deployments at each station. After collection, cores were extruded and the resulting sediment was fixed into a $4 \%$ formalin solution and maintained at $4^{\circ} \mathrm{C}$ until laboratory analyses. In lab, sediments were sieved through 1000 and 37 $\mu \mathrm{m}$ mesh nets. The fraction remaining on the $37 \mu \mathrm{m}$ sieve was centrifuged three times with Ludox HS (density $1.18 \mathrm{~g}$ $\mathrm{cm}^{-3}$ ). All meiobenthic animals were counted and classified per taxon under a stereo microscope after staining with Rose Bengal $\left(0.5 \mathrm{~g} \mathrm{~L}^{-1}\right)$ as described in Danovaro et al. [16]. Total number of taxa and total number of individuals were calculated for each station.

The quali-quantitative analyses of macrozoobenthos were performed following the methodology described by ICRAM [14]. Sediment samples (two replicates resulting from independent deployments of the grab) were collected and sieved using $0.5 \mathrm{~mm}$ mesh, by gently rinsing the sediment with filtered marine water. The sieved samples were fixed into a $4 \%$ formalin solution and maintained at $4{ }^{\circ} \mathrm{C}$ until laboratory analyses. Organisms of each replicate were then sorted under the main taxonomical groups, analyzed under stereomicroscope (Zeiss STEMI 2000) and stored in an alcohol solution (70\% final concentration) for the subsequent taxonomical analyses performed under microscope (Zeiss Axiolab). Abundances of total organisms and of the major taxonomical groups (Crustacea, Mollusca, Anellida, Nematoda and Others) were provided.

The following biotic indexes were calculated on the macrozoobenthos community: total species number (S), Shannon index $\left(\mathrm{H}^{\prime}=-\mathrm{p}_{\mathrm{i}} \Sigma \log _{2} \mathrm{p}_{\mathrm{i}}\right)$ and Pielou index (evenness, $\mathrm{J}=\mathrm{H}^{\prime} / \mathrm{H}_{\max }$ ).

Visual Census, Determinations of Phenological and Lepidochronological variables of P.oceanica

At all the stations, the determination of the bottom coverage and shoots density of $P$. oceanica was performed in immersion by scientific SCUBA divers, according to ICRAM [14]. Moreover, samples of rhizomes and shoots were collected by SCUBA divers and stored at $4{ }^{\circ} \mathrm{C}$ for phenological and lepidochronological analyses [14]. In particular, the following parameters were calculated:
Shoots density and coverage. At each station, shoots were counted (in triplicate) on a surface of $1 \mathrm{~m}^{2}$. Estimate of the coverage of the bottom by $P$. oceanica was carried out independently by the two divers by visual census.

Leaf biomasses. After collection, leaves were isolated, dried $\left(70^{\circ} \mathrm{C}\right.$ for $\left.72 \mathrm{~h}\right)$ and weighed by means of an analytical balance (SARTORIUS, CPA 225D).

Annual leaf production: Annual leaf production was determined through lepidochronological analyses, carried out according to [14]. Leaf production was calculated as follows:

$$
\mathrm{P}=\mathrm{N} \cdot \mathrm{D} \cdot \mathrm{L}
$$

where $\mathrm{N}$ is the average number of leaves per shoot per year, $\mathrm{L}$ is the average annual length of the leaves, $\mathrm{D}$ is the average annual density of old leaves $\left(\mathrm{mg} \mathrm{cm}^{-1}\right)$. The annual leaf production was provided in $\mathrm{g} \mathrm{m}^{-2}$ year ${ }^{-1}$ d.w..

Leaf Area Index (L.A.I.): The LAI index is calculated as the sum of L.A.I. of adult and intermediate leaves. According with Drew [17], each L.A.I. is calculated as follows:

L.A.I. $=$ average leaf length $\cdot$ average leaf width $\cdot$ average leaf number

\section{RESULTS}

\section{Hydrological Setting}

All the average values in the Results section are provided as \pm Standard Error.

The hydrological data collected revealed a typical seasonal variability of the study area and a reduced stratification of the water column (Table 1). In June $2009\left(23.93 \pm 0.8^{\circ} \mathrm{C}\right)$ temperature values were higher than November 2009 $\left(16.37 \pm 0.1^{\circ} \mathrm{C}\right)$, with reduced differences among surface and bottom waters lower then $1^{\circ} \mathrm{C}$.

Salinity was homogeneous in the study area, with similar values among surface and bottom waters and with a difference of about 1 psu between June (36.59 \pm 0.2 psu) and November $(37.51 \pm 0.1 \mathrm{psu})$.

The concentrations of dissolved oxygen, very homogeneous along the water column and on a seasonal time scale suggested a good oxygenation of surface and bottom water layers, with values ranging from $6.80 \pm 0.3$ and $7.05 \pm 0.2 \mathrm{mg}$ $\mathrm{L}^{-1}$ in June and November 2009, respectively.

The concentration of chlorophyll $a$ and inorganic nutrients (total $\mathrm{N}, \mathrm{NO}_{2}, \mathrm{NO}_{3}, \mathrm{NH}_{4}{ }^{+}$, total $\mathrm{P}, \mathrm{PO}_{4}$ ) collected from surface and bottom waters (Table 1) revealed a homogeneous and oligotrophic environment, with some difference among seasons, and values lower than previous data on Apulian coastal monitoring [18]. Content of $\mathrm{NO}_{3}(20.59 \pm 10$ $\left.\mu \mathrm{g} \mathrm{L}^{-1}\right)$ and $\mathrm{NH}_{4}\left(10.76 \pm 4.9 \mu \mathrm{g} \mathrm{L}^{-1}\right)$ in the study area was slightly higher in June 2009 than November $2009\left(\mathrm{NO}_{3}\right.$ : $8.51 \pm 3.6 \mu \mathrm{g} \mathrm{L}^{-1} ; \mathrm{NH}_{4}: 2.47 \pm 1.2 \mu \mathrm{g} \mathrm{L}^{-1}$ ).

\section{Physico-Chemical and Chemical Variables in Sediments}

Results obtained by the granulometric analyses in June and November 2009 are shown in Table 2. Sedimentological analyses revealed that the fraction $>2 \mathrm{~mm}$ was completely represented by organogenic particles, ranging on average 
Table 1. Average Values of Physico-Chemical Variables and Concentrations of Inorganic Nutrients and Chlorophyll $a$ in Seawater in the Study Area in the Two Sampling Periods. Standard Deviations were also Reported for Each Parameters. B.d.l. = Below Detection Limits

\begin{tabular}{|c|c|c|c|c|c|c|c|c|c|c|c|}
\hline $\begin{array}{l}\text { Sampling } \\
\text { Period }\end{array}$ & $\begin{array}{l}\text { Water Column } \\
\text { Depth }\end{array}$ & $\begin{array}{c}\text { Temperature } \\
\left({ }^{\circ} \mathbf{C}\right)\end{array}$ & $\begin{array}{c}\text { Salinity } \\
\text { (psu) }\end{array}$ & $\begin{array}{c}\text { Dissolved } \\
\text { Oxygen } \\
\left(\mathrm{mg} \mathrm{L}^{-1}\right)\end{array}$ & $\begin{array}{l}\text { Chl a* } \\
\left(\mu \mathrm{g} \mathrm{L}^{-1}\right)\end{array}$ & $\underset{\left(\mu \mathrm{g} \mathrm{L}^{-1}\right)}{\mathbf{N}_{\text {tot }}}$ & $\begin{array}{c}\mathrm{NO}_{3} \\
\left(\mu \mathrm{g} \mathrm{L} \mathbf{L}^{-1}\right)\end{array}$ & $\underset{\left(\mu \mathrm{g} \mathrm{L}^{-1}\right)}{\mathbf{N H}_{4}}$ & $\begin{array}{c}\mathrm{NO}_{2} \\
\left(\mu \mathrm{g} \mathrm{L} \mathbf{L}^{-1}\right)\end{array}$ & $\begin{array}{c}\mathbf{P O}_{4} \\
\left(\mu \mathrm{g} \mathrm{L} \mathbf{L}^{-1}\right)\end{array}$ & $\underset{\left(\mu \mathrm{g} \mathrm{L}^{-1}\right)}{\mathbf{P}_{\text {Tot }}}$ \\
\hline \multirow{2}{*}{$\begin{array}{l}\text { June } \\
2009\end{array}$} & Surface & $24.16 \pm 0.9$ & $34.46 \pm 0.2$ & $6.59 \pm 0.3$ & B.d.l. & $171 \pm 61$ & $25.69 \pm 9.1$ & $9.71 \pm 4.8$ & $1.32 \pm 0.2$ & $1.80 \pm 0.3$ & $12.70 \pm 3.1$ \\
\hline & Bottom & $23.78 \pm 0.7$ & $36.66 \pm 0.1$ & $6.94 \pm 0.4$ & B.d.l. & $137 \pm 17$ & $15.49 \pm 10$ & $11.82 \pm 5$ & $1.56 \pm 0.3$ & $1.51 \pm 0.4$ & $9.24 \pm 3.4$ \\
\hline \multirow{2}{*}{$\begin{array}{l}\text { November } \\
2009\end{array}$} & Surface & $16.42 \pm 0.1$ & $37.48 \pm 0.1$ & $6.92 \pm 0.1$ & B.d.l. & $169 \pm 20$ & $8.69 \pm 3.7$ & $2.54 \pm 1.3$ & $5.79 \pm 1.5$ & $1.78 \pm 0.3$ & $7.30 \pm 2.7$ \\
\hline & Bottom & $16.33 \pm 0.2$ & $37.55 \pm 0.02$ & $7.05 \pm 0.2$ & B.d.l. & $158 \pm 20$ & $8.33 \pm 3.7$ & $2.40 \pm 1.3$ & $6.07 \pm 1.2$ & $1.46 \pm 0.4$ & $9.13 \pm 3.5$ \\
\hline
\end{tabular}

*Detection limit $=1 \mu \mathrm{g} \mathrm{L}^{-1}$

from $11.4 \pm 17 \%$ dry sediment (d.s.) to $31.4 \pm 13 \%$ d.s. in the coastal area (stations $1 \mathrm{M} 1,1 \mathrm{M} 2,2 \mathrm{M} 1,2 \mathrm{M} 2,3 \mathrm{M} 1$ and $3 \mathrm{M} 2$ ) and in the off-shore area (1M3, 2M3, 3M3), respectively. The resulting component was represented by terrigenous sediments, characterized by a sandy texture $(99.15 \pm 0.60 \%)$. No major differences were detected among sampling periods.

Concentrations of trace metals and Total Organic Carbon (TOC) in the study area are reported in Table 2 . The average concentrations of TOC in all the 9 stations investigated in this study ranged from $0.15 \pm 0.1$ to $0.33 \pm 0.06 \%$ d.s., in November and June, respectively, with homogeneous values in the investigated area.

The concentrations of trace metals in surface sediments were very low in all stations and in both sampling periods, without any evident pattern in the study area.

Al displayed average concentrations in surface sediments of the study area ranging from $6532 \pm 2264$ to $8785 \pm 2264 \mathrm{mg}$ $\mathrm{kg}^{-1}$ d.s. (in June and November, respectively), with higher values in the coastal area comparing with the off-shore area in both sampling periods.

As displayed average concentrations in the surface sediments of the study area ranging from $5.33 \pm 1.20$ to $10.66 \pm 1.15 \mathrm{mg} \mathrm{kg}^{-1}$ d.s. (in June and November, respectively).

The concentrations of $\mathrm{Cd}$ were below the detection limit ( $0.1 \mathrm{mg} \mathrm{kg}^{-1}$ dry sediment) in all the 9 stations and in both the sampling periods.

The concentrations of Total $\mathrm{Cr}$, in both sampling periods, generally decreased with increasing the distance from the coast. Average values in the study area ranged from $4.22 \pm 0.6$ to $11 \pm 3.2 \mathrm{mg} \mathrm{kg}^{-1} \mathrm{~d}$.s. (in June and November, respectively).

The concentrations of Fe displayed a homogeneous distribution in the study area in both sampling periods, with average values ranging from $1818 \pm 278$ to $2558 \pm 240 \mathrm{mg} \mathrm{kg}^{-1}$ d.s. (in June and November, respectively).

The concentrations of $\mathrm{Pb}$ generally displayed the highest values in coastal stations in both periods, with average values ranging from $4.91 \pm 1.12$ to $6.01 \pm 0.90 \mathrm{mg} \mathrm{kg}^{-1}$ d.s. (in June and November, respectively).

The concentrations of $\mathrm{Cu}$ and $\mathrm{Zn}$ were rather homogeneous in the study area, with an average value of $1.16 \pm 0.26 \mathrm{mg}$ $\mathrm{kg}^{-1}$ d.s. for $\mathrm{Cu}$ and $8.79 \pm 0.89 \mathrm{mg} \mathrm{kg}^{-1}$ d.s. for $\mathrm{Zn}$, in both sampling periods. $\mathrm{Cu}$ concentrations were below the detection limit ( $1 \mathrm{mg} \mathrm{kg}^{-1} \mathrm{~d}$.s.) or slightly higher.

\section{Chemical Variables in Tissues of Posidonia Oceanica}

The concentrations of heavy metals in leaves and rhizomes of Posidonia oceanica are represented in Figs. (2) and (3), respectively. Al displayed the highest values in samples collected in November 2009, when concentrations were up to 2-3 times higher than those of the June 2009, reaching $125 \pm 54$ and $140 \pm 66 \mathrm{mg} \mathrm{kg}^{-1}$ dry weight (d.w.) in leaves and rhizomes, respectively.

As and $\mathrm{Pb}$ concentrations displayed some values below the detection limit $\left(1 \mathrm{mg} \mathrm{kg}^{-1} \mathrm{~d}\right.$. w.). The remaining values ranged from 1 and $3 \mathrm{mg} \mathrm{Kg}^{-1} \mathrm{~d}$. w. in leaves and rhizomes and in both sampling periods.

The concentrations of $\mathrm{Cd}$ were always higher in leaves than in rhizomes, ranging on average from $2.94 \pm 0.60$ to $5.49 \pm 0.90 \mathrm{mg} \mathrm{kg}^{-1} \mathrm{~d}$. w. in leaves (in November and June, respectively). The spatial distributions of $\mathrm{Cd}$ in Posidonia tissues generally increased with the distance from the coast in both matrices.

Total $\mathrm{Cr}$ displayed very low concentrations, ranging from $0.35 \pm 0.20$ to $0.73 \pm 0.20 \mathrm{mg} \mathrm{kg}^{-1} \mathrm{~d}$. w. in leaves (in June and November, respectively), whereas in rhizomes concentrations ranged from $0.59 \pm 0.20$ to $0.96 \pm 0.60 \mathrm{~d}$. w. (in June and November, respectively).

The concentrations of $\mathrm{Fe}$ were always higher in rhizomes $\left(279 \pm 72 \mathrm{mg} \mathrm{kg}^{-1} \mathrm{~d}\right.$. w.) than in leaves $\left(117 \pm 45 \mathrm{mg} \mathrm{kg}^{-1} \mathrm{~d}\right.$. w.), with the maximum values in November 2009.

The concentrations of $\mathrm{Cu}$ were slightly higher in leaves than in rhizomes, ranging on average from $12.1 \pm 0.9$ to $19.1 \pm 2.1 \mathrm{mg} \mathrm{kg}^{-1} \mathrm{~d}$. w. in leaves (in June and November, respectively), whereas in rhizomes concentrations ranged from $9.5 \pm 1.6$ to $12.9 \pm 1.9 \mathrm{~d}$. w. (in June and November, respectively).

The concentrations of $\mathrm{Zn}$ were 2 -folds higher in leaves $\left(125 \pm 26 \mathrm{mg} \mathrm{kg}^{-1} \mathrm{~d}\right.$. w.) than in rhizomes $\left(61.5 \pm 16 \mathrm{mg} \mathrm{kg}^{-1} \mathrm{~d}\right.$. w.), with the maximum values in November 2009.

\section{Quali-Quantitative Determinations of Benthic Communities}

The abundance of meiofauna ranged, in June, from $204 \pm 114$ (standard deviation, S.D.) to $926 \pm 427$ ind. $10 \mathrm{~cm}^{-2}$ 
Table 2. Grain Size Values, Total Organic Carbon - TOC and Heavy Metal Concentrations in the Investigated Sediments in the Two Sampling Periods (June and November 2009). d.s. = dry Sediment; B.d.l. = Below Detection Limits

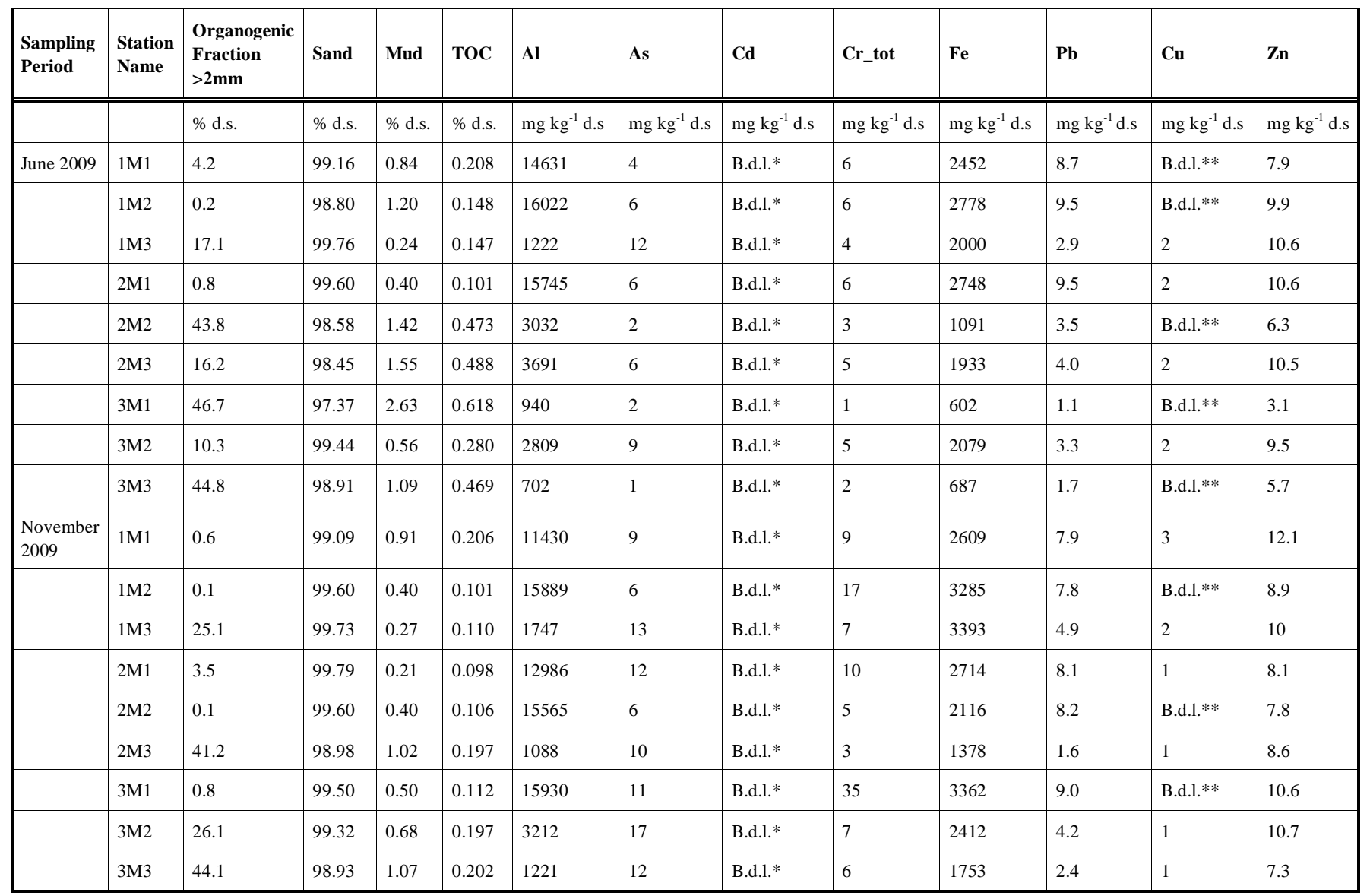

Sand and mud fractions were calculated at $100 \%$.

* Detection limit $=0.1 \mathrm{mg} \mathrm{kg}^{-1}$

$* *$ Detection limit $=1 \mathrm{mg} \mathrm{kg}^{-1}$

at stations 3M3 and 2M1, respectively (Fig. (4), on average $506 \pm 93$ ind. $10 \mathrm{~cm}^{-2}$ ). In November, the abundances ranged from $96 \pm 27$ to $1438 \pm 229$ at stations $3 \mathrm{M} 3$ and $3 \mathrm{M} 1$ (Fig. (4a), on average $562 \pm 149$ ind. $10 \mathrm{~cm}^{-2}$ ).

The study area was characterized by the presence of the most common taxa in Mediterranean sediments: Nematoda, Copepoda and Polychaeta representing, on average, $90 \%$ in June and $89 \%$ of the entire community in November. A minor fraction of organisms are represented by Mollusca, Cumacea, Amphipoda, Tanaidacea (represented in Fig. (4b) as "Others").

The abundances of macrozoobenthos ranged, in June, from $2637 \pm 755$ to $10403 \pm 1999$ ind. $\mathrm{m}^{-2}$ at stations $3 \mathrm{M} 2$ and 3M3 (Fig. 5a). In November, the abundances ranged from $712 \pm 128$ to $6489 \pm 1302$ at stations $2 \mathrm{M} 2$ and $2 \mathrm{M} 1$. On average, the total abundance of macrozoobenthos in June was $6080 \pm 903$ ind. $\mathrm{m}^{-2}$ whereas in November was $2521 \pm 605$ ind. $\mathrm{m}^{-2}$.

The collected organisms were divided into a total of 117 taxa in June and 84 taxa in November. The larger fraction of organisms were owed to taxa of Polychaeta and Nematoda (Fig. 5b), the first representing $42.5 \%$ in June and $59.8 \%$ of the total organisms found in November, whereas the latter representing $35.0 \%$ in June and $14.0 \%$ in November. Crustacea represented the third most abundant taxa, representing $15.3 \%$ in June and $16.6 \%$ in November. The other taxa (mainly Mollusca, Echinodermata, Cephalochordata, Sipunculida) represented together $7.3 \%$ and $9.3 \%$ in June and November.

The Shannon index, calculated on each sampling period, was $3.87 \pm 0.25$ in June and $3.36 \pm 0.23$ in November. The Evenness index was $0.78 \pm 0.03$ in June and $0.80 \pm 0.04$ in November.

\section{Visual Census, Phenological and Lepidochronological Variables of P.oceanica}

Visual census performed by SCUBA divers on the study area revealed a heterogeneous bottom, with the presence of sandy areas, hard organogenous substrates and areas covered by P.oceanica. Average cover and shoots density displayed very similar values in the two sampling periods. Cover ranged from 10 to $90 \%$ (Fig. 6a) with lowest values in the most coastal stations (1M1, 2M1, 3M1). The shoot density ranged from 121 (station 2M3) to 343 (station 3M2) shoots 
Al

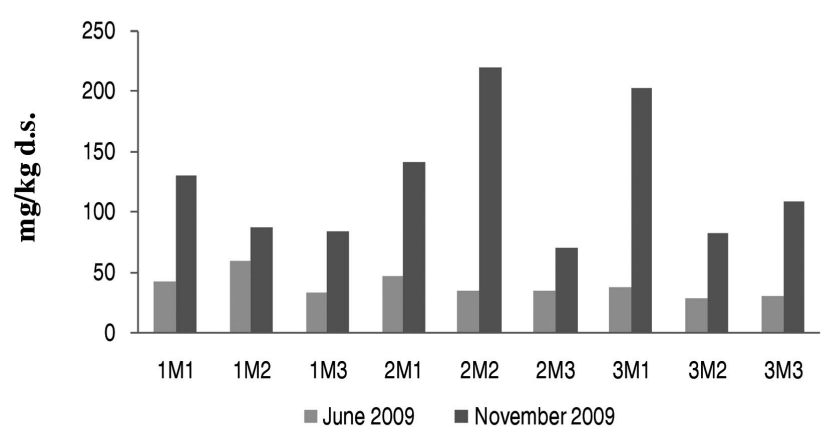

As

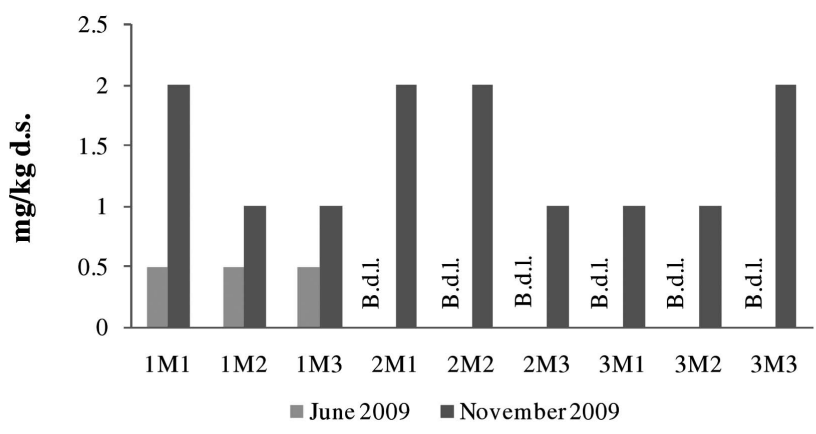

Cd

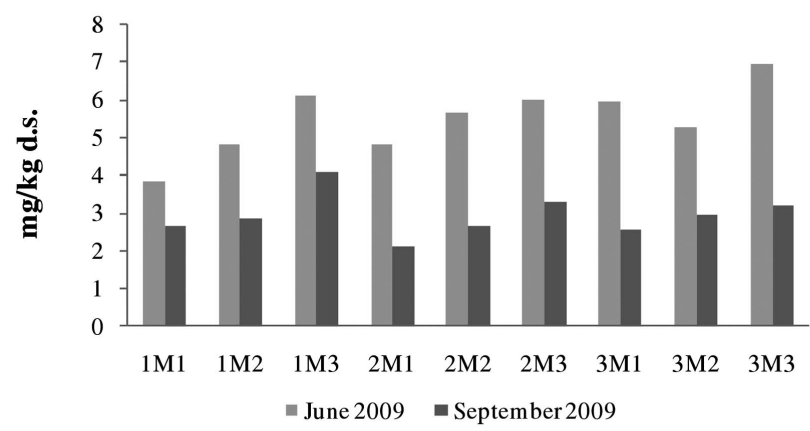

Total Cr

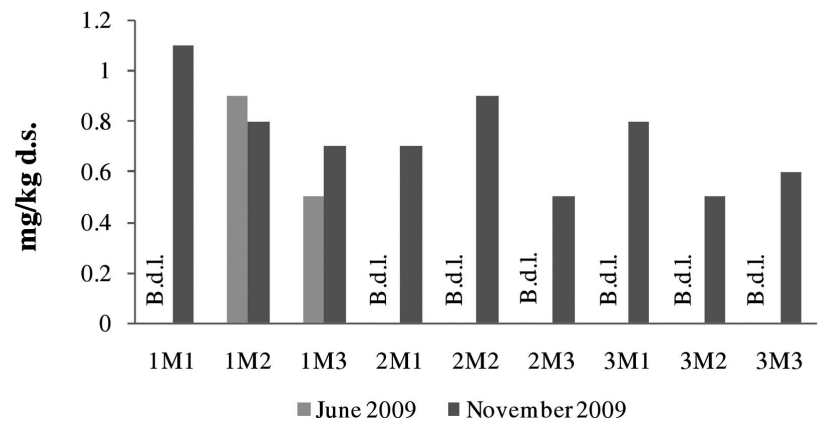

$\mathrm{Cu}$

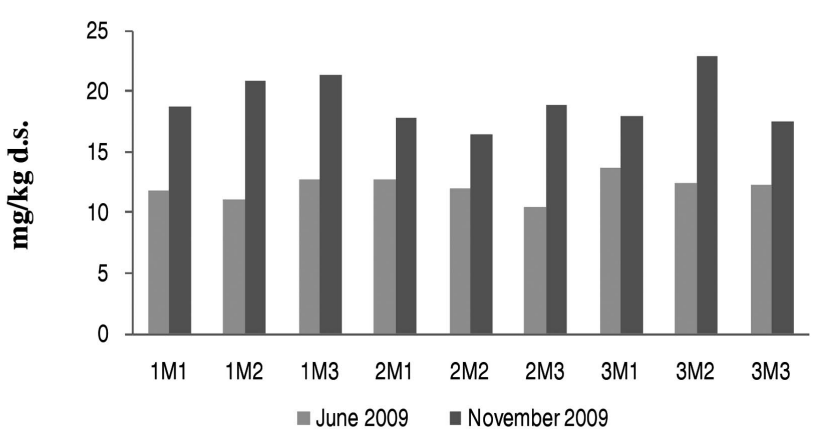

Fe

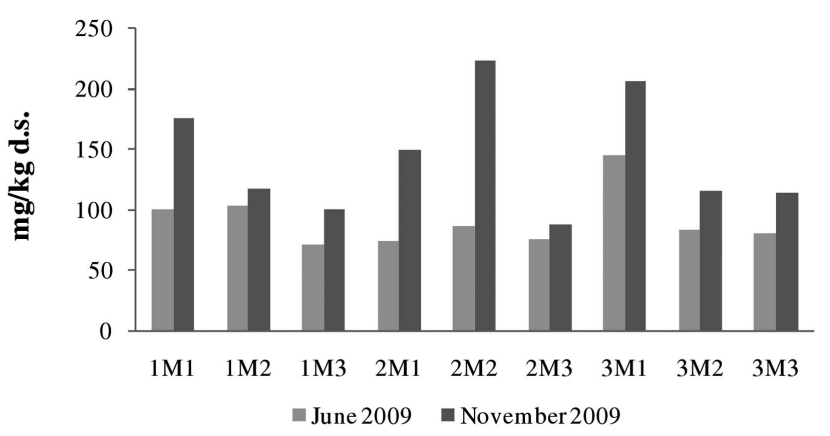

$\mathbf{P b}$

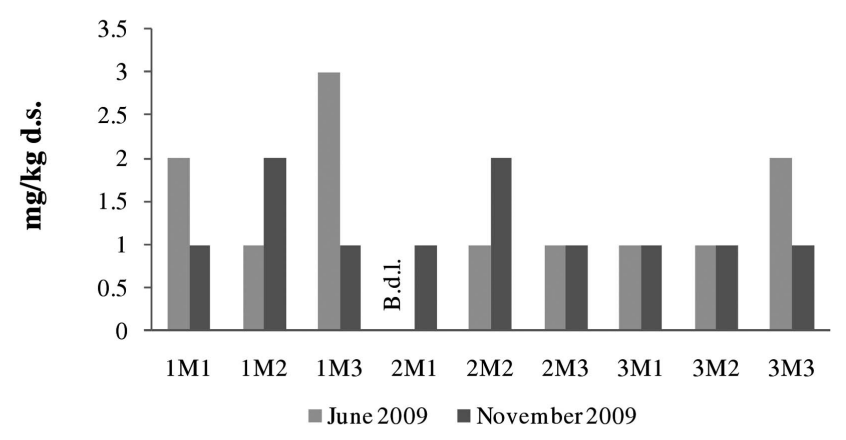

Zn

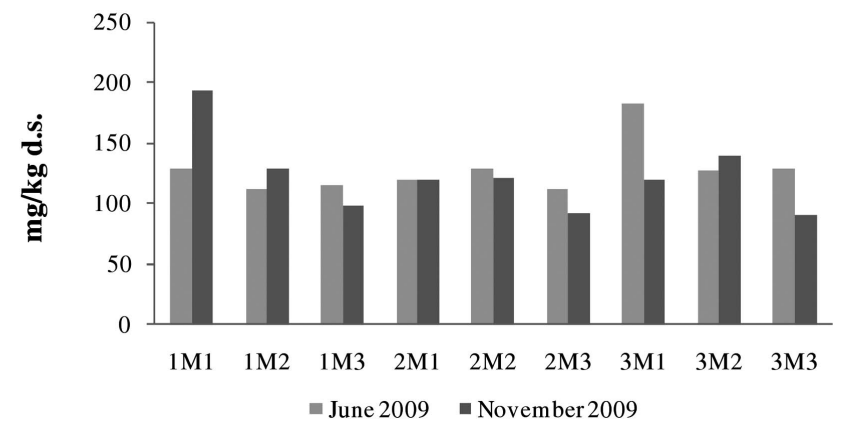

Fig. (2). Concentrations of metals in leaves of P. oceanica. 
Al

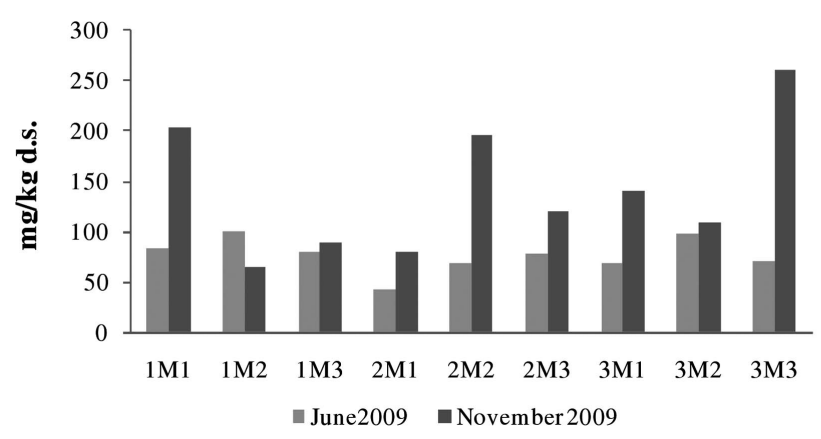

As

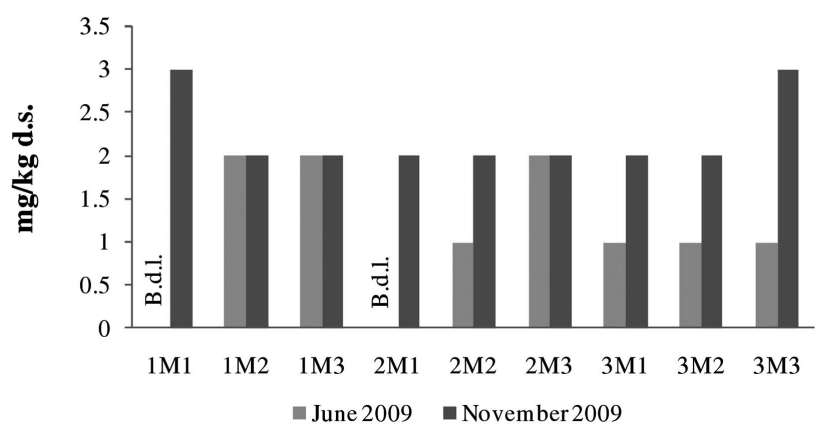

Cd

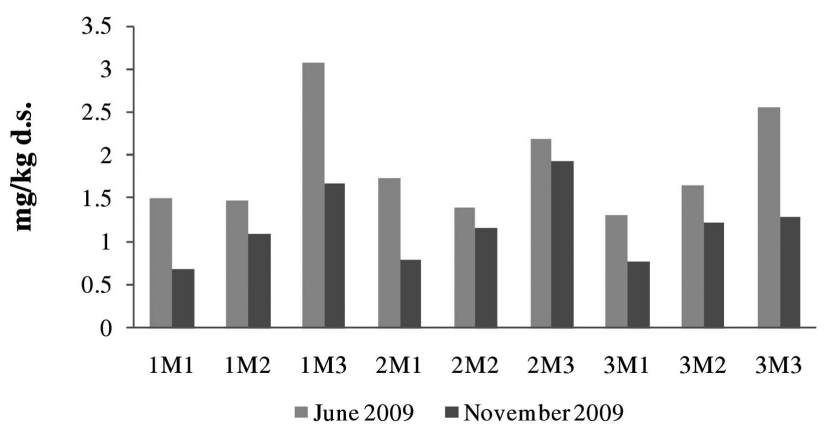

Total Cr

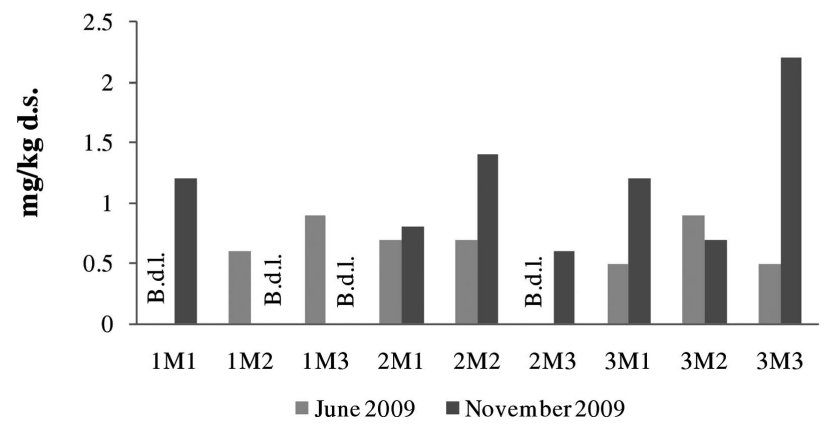

$\mathrm{Cu}$

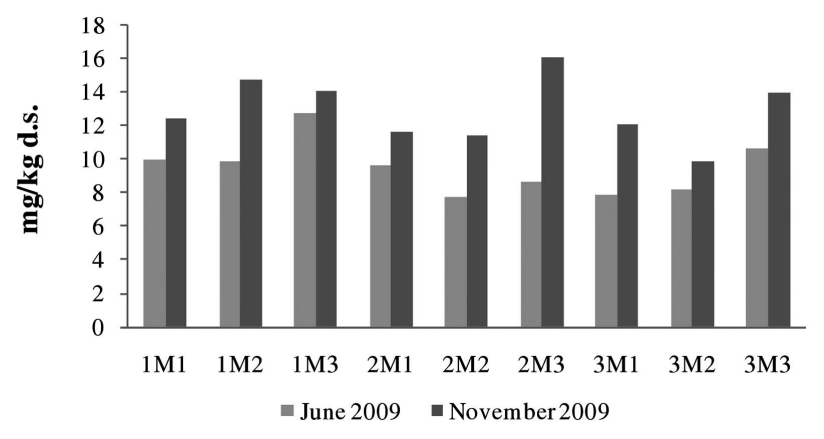

Fe

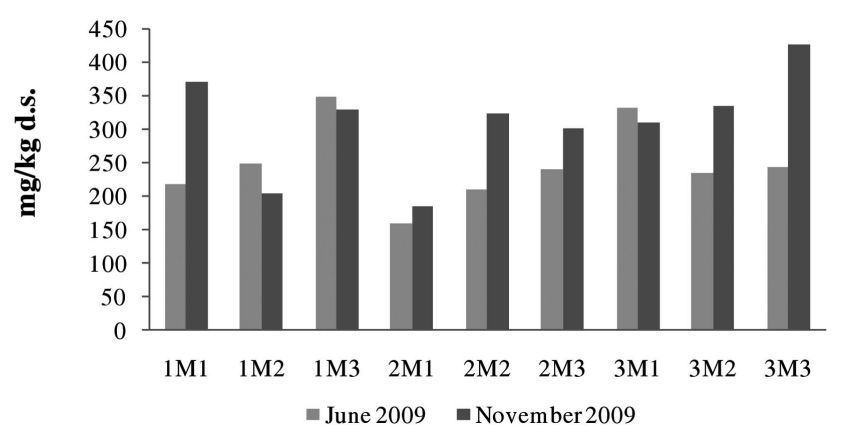

$\mathbf{P b}$

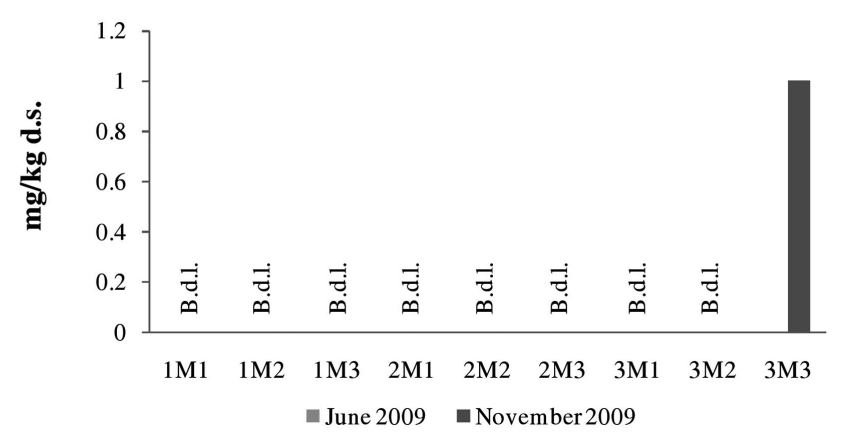

Zn

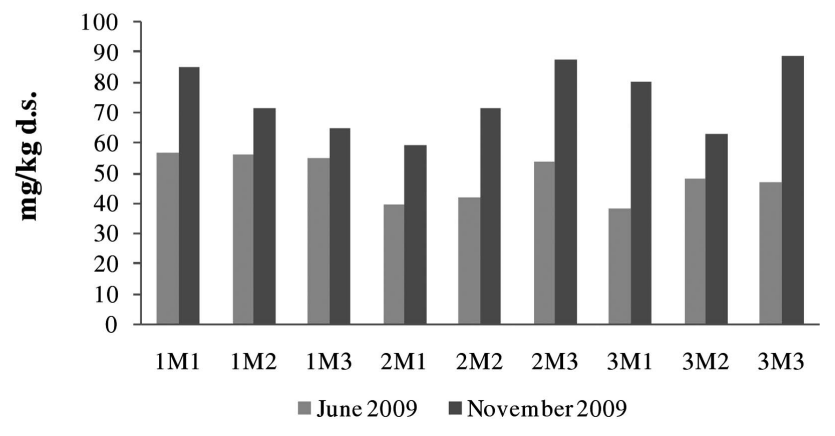

Fig. (3). Concentrations of metals in rhizomes of P. oceanica. 
Meiobenthic community abundance

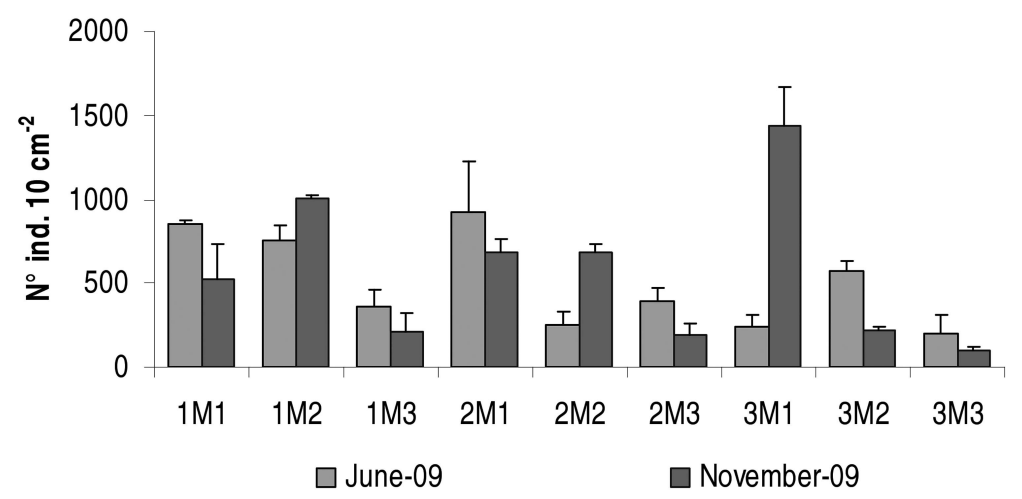

June 2009

November 2009

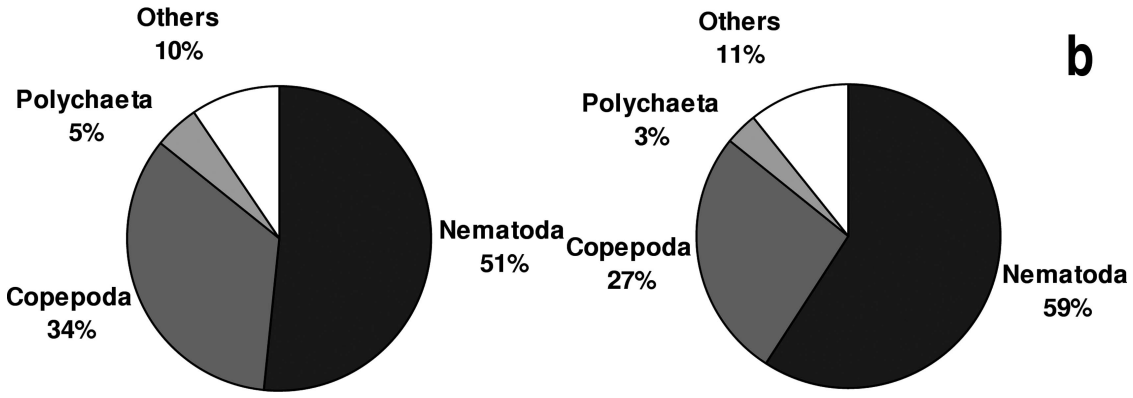

Fig. (4). Meiobenthic community abundance (a) and structures (b) in June and November 2009.

Macrobenthic community abundance

a

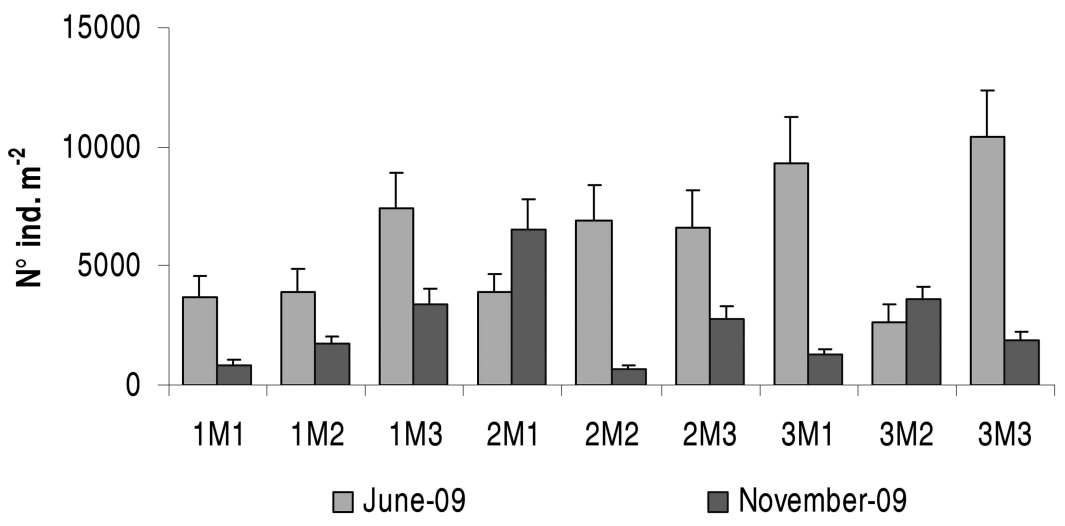

June 2009

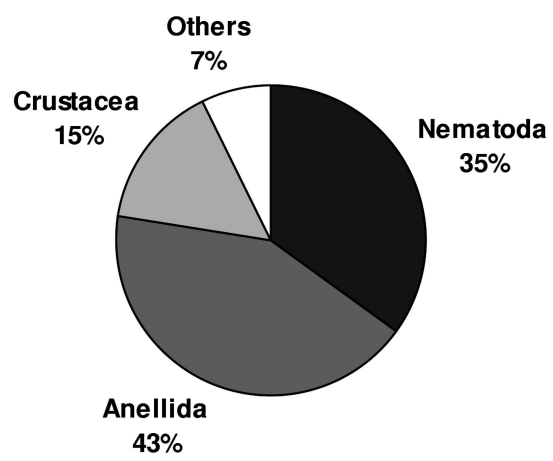

November 2009

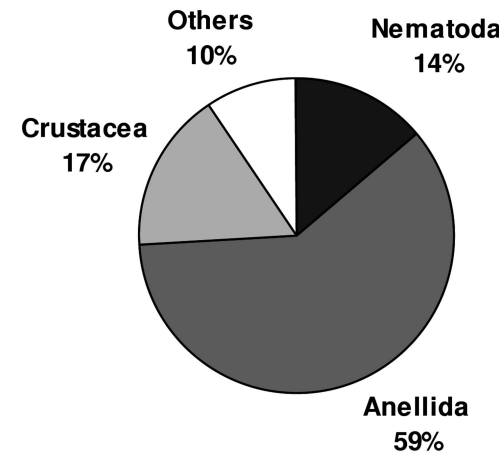

Fig. (5). Macrozoobenthic community abundance (a) and structures (b) in June and November 2009. 


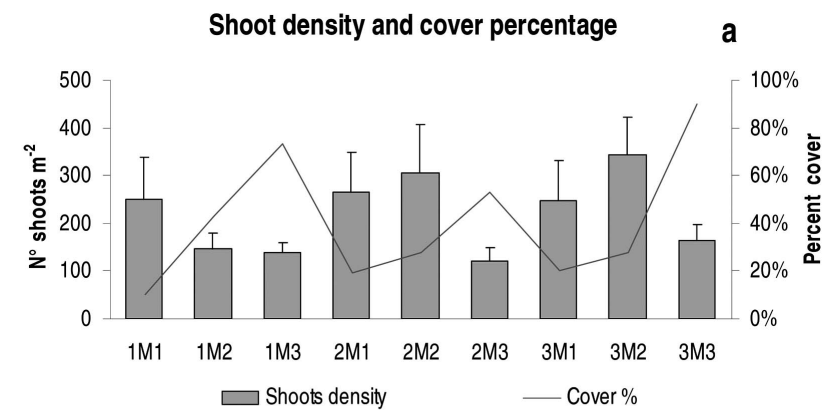

Annual leaf production

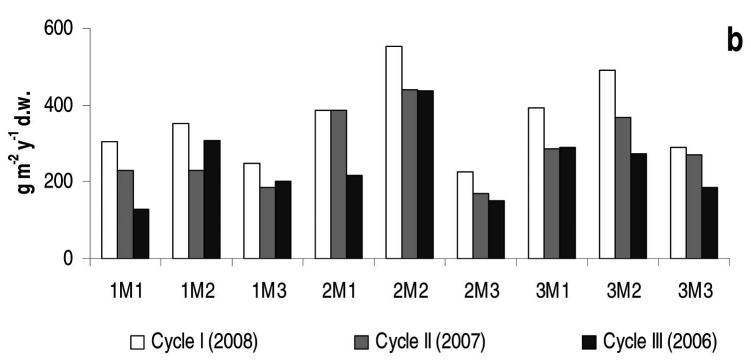

Fig. (6). Shoot density and coverage of P. oceanica meadow (a) and annual leaf production in the last three lepidochronological cycles (b).

$\mathrm{m}^{-2}$. The L.A.I. values ranged from 2.82 to 4.90 at stations $2 \mathrm{M} 1$ e $3 \mathrm{M} 1$ respectively, with an average value on the study area of 3.87. The distribution of the L.A.I. values among the investigated stations didn't follow any clear pattern. The leaf biomass ranged from $93 \pm 9$ to $242 \pm 4 \mathrm{~g} \mathrm{~m}^{-2} \mathrm{~d}$.w. at stations $2 \mathrm{M} 3$ and $3 \mathrm{M} 1$, respectively.

The annual leaf production was calculated on the basis of sheaths of the three most recent lepidochronological cycles (I, II, III referring to 2008, 2007, 2006, Fig. (6b)). Average values of annual leaf production ranged from $182 \pm 40$ to $476 \pm 66 \mathrm{~g} \mathrm{~m}^{-2} \mathrm{y}^{-1} \mathrm{~d} . \mathrm{w}$. at stations $2 \mathrm{M} 3$ and $2 \mathrm{M} 2$ respectively. The three lepidochronological cycles displayed similar values with a slight increase of leaf production over time.

\section{DISCUSSION}

Marine coastal waters, especially in anthropized areas, are influenced by terrigenous inputs and subjected to allochthonous chemical and trophic inputs through municipal, agricultural and industrial effluent discharges and atmospheric depositions. As a result, the biota of marine coastal areas is potentially subjected to the chemical inputs influencing the quality of waters and sediments. Among the key ecosystemic components of the study area, major roles are played by the benthic fauna and by the marine phanerogam P.oceanica. Meio-macrozoobenthos and P.oceanica are known to be particularly sensitive to chemical pollution of sediments and overlying waters [19-21], also because of their capability to bioaccumulate contaminants in tissues. Therefore, an exhaustive analysis of environmental health status should include not only the study and quantification of potential contamination in seawater and sediments, but also the analysis of the key biological components.
In this study, physico-chemical and chemical variables of seawater revealed a homogeneous and oligotrophic environment with a typical seasonal variability of the study area.

Grain size, TOC and heavy metals concentrations in surface sediments highlighted a substantial homogeneity with some difference among stations. On average, the concentrations of trace metals were very low, sometimes below the detection limits (i.e. cadmium) and always below the threshold limits of national and international sediment quality criteria. This is in agreement with the previous monitoring results in the Brindisi area [18].

Furthermore, metal values were higher in November than in June, suggesting that inputs of such elements reaching the sediments could be partially subjected to slight seasonal variability.

There is currently a great interest in the use of marine organisms as pollution biomonitors in aquatic ecosystems [11] given that the previously used method of chemical analysis of water does not provide sufficient information on the bioavailability of contaminants present in the environment [22]. The seagrass Posidonia oceanica is considered a useful bio-indicator due to its predisposition to accumulate metals in tissues [11, 23-27]. In the present study, the repartition of the trace metals analyzed between the two tissues of Posidonia oceanica considered (leaves and rhizomes) showed a seasonal trend. In June, our results suggest that $\mathrm{Cd}, \mathrm{Cu}, \mathrm{Pb}$ and $\mathrm{Zn}$ are preferentially accumulated in leaves, whereas $\mathrm{Al}$, $\mathrm{As}, \mathrm{Cr}$ and $\mathrm{Fe}$ were more concentrated in rhizomes. In November, the concentrations of $\mathrm{Al}$ were equal in leaves and rhizomes, whereas $\mathrm{Cd}, \mathrm{Cr}, \mathrm{Cu}, \mathrm{Pb}$ and $\mathrm{Zn}$ were preferentially accumulated in leaves, with reduced concentrations in rhizomes. Only As and Fe showed higher concentrations in rhizomes than in leaves in November. This finding is in agreement with previous studies [23, 27, 28] and leads to the hypothesis of a preferential uptake of $\mathrm{Cd}, \mathrm{Cu}, \mathrm{Pb}$ and $\mathrm{Zn}$ from the water column to the photosynthetic tissue.

The concentrations of the trace metals investigated in this study (in both leaves and rhizomes) fall in the range of the lowest values available in the literature and typical of pristine areas. Our concentrations of $\mathrm{Cd}$ and $\mathrm{Pb}$ are much lower than those found for the impacted site of Antikyra Gulf in Greece [29], whereas the concentrations of $\mathrm{Cr}$ were lower than those found in an impacted site of the Aegean Sea [30]. The comparison of the concentration of trace metals in Posidonia tissue revealed significant differences among June and November for all the investigated variables. Seasonal and temporal differences in trace metal concentrations are considered to be a function related to seagrass growth cycles, sediment resuspension, runoff from the land, fluvial inputs as well as microbial degradation [31]. Previous studies have suggested that seasonal differences in seagrass metal concentrations are a result of productivity and growth rates, as rapid growth can cause a dilution of metals within the plant tissue [32].

The analysis of benthic communities, for their high sensitivity to environmental stress, is considered a useful tool for the assessment of the health status of ecosystem. In particular, meiofauna, due to the reduced size of organisms, their short life cycles and lacking of larval dispersion [33] is able 
to provide rapid responses to environmental modifications [34].

The abundances of meiofauna, thus falling in the range reported in literature for marine coastal sediments [35], were relatively low. Such reduced abundances of meiofaunal organisms found are probably related to the high percentages of huge granulometric classes (sands and organogenic fraction $>2 \mathrm{~mm}$ ) found in the study area, which could affect meiofauna as a reduction of the optimal habitat, represented by fine sands and muds [36], for these interstitial organisms.

Meiofaunal parameters (abundances and community composition) displayed a high variability among stations and among data collected in the same station in the two sampling periods, even though no clear spatial or temporal patterns were found. Despite such spatial and temporal variability of data, the average number of organisms and the community composition in the study area was very similar in the two sampling periods. This evidence leads to the hypothesis of an important role for the heterogeneity of the substrate (in which the sandy areas coexist with hard substrates and Posidonia patches), which could drive the spatial distribution of organisms to an irregular and patched distribution, responsible of the observed spatial variability and of the apparent temporal variability.

The investigated area is characterized by macrobenthic biocoenoses typical of CSBC (Coarse Sands and fine gravel under the influence of Bottom Currents; [37]). Total abundances of macrozoobenthos fall in the ranges reported in the literature for Mediterranean sediments [38-40] and displayed a slight seasonal variability (Fig. 5). The macrobenthic assemblages displayed patchy distributions, without any evident patterns (Fig. 5); this result, together with the high spatial variability found among stations, could reflect the high heterogeneity of the area, evidencing the presence of different kinds of habitats. This hypothesis is strengthened by the high biodiversity of macrozoobenthos (expressed in terms of Shannon and Evenness) found in both the sampling periods. In particular, the marked variability of results among stations and among the two sampling periods could be related not only to seasonal variability but also to the high heterogeneity of substrates (rocks and coralligenous, Posidonia mattes and sandy areas). Such heterogeneity, and the potential accumulation of dead leaves of P.oceanica could influence also the macrobenthic community composition, favoring the presence of high percentages of Oligochaeta (as reported in [41]) found in some stations (data not shown). The high abundances of macrofauna and the biodiversity found in this study suggest a global good status of health of the ecosystem.

The visual census performed on the area by SCUBA divers provided a relatively low shoot density of $P$. oceanica (121-343 shoots $\mathrm{m}^{-2}$ ), although falling in the range of data available in literature for Mediterranean coastal sites (e.g. 144-941 shoots $\mathrm{m}^{-2}$, [42]; 353-473 shoots $\mathrm{m}^{-2}$, [20]; 433-513 shoots $\mathrm{m}^{-2}$, [43]). These data allowed the meadow to be described as "Type 3, 4 and 5" (from very sparse to sparse bed, [44]). The shoot density displayed lowest values in the offshore station than in the two costal stations of all the investigated transects (Fig. 6). An opposite trend was displayed by the cover percentage and by the primary leaf production, showing a clear increase with depth and distance from the coast. These trends are probably linked to the gradual decrease of light with increasing depth from the coastal to the off-shore stations (depth range: $4-14 \mathrm{~m}$ ), as reported by [44, 45].

The average number of leaves shoot $^{-1}$ (4.8) was influenced by the very low number of juvenile leaves (length less than $50 \mathrm{~mm}$ without sheath), probably linked to the seasonal variability of this parameter. Specifically, even though new leaves are continuously produced by the phanerogam over the year, the production rates follow seasonal cycles, with minima in Spring and maxima in Autumn [46-48].

The L.A.I. index, a synthetic descriptor of the amount of photosynthetic tissue, varied in a reduced range, without any evident pattern linked to water depth or distance from the coast. This parameter is mainly linked to the shoot density, and is also influenced by the grazing activity of epibiota and fish assemblages.

Estimates of the leaf production were performed considering leaves of the present cycle and shoots of the three most recent lepidochronological cycles (I, II and III) corresponding to years 2008, 2007, 2006. The leaf production shoot ${ }^{-1}$ (ranging from 0.89 to $2.03 \mathrm{~g} \mathrm{~d} . \mathrm{w}$. $\operatorname{shoot}^{-1} \mathrm{y}^{-1}$ ), fall in the range of values reported in literature $(0.86 \div 1.42 \mathrm{~g} \mathrm{~d} . \mathrm{w}$. shoot $\mathrm{y}^{-1}$, [49]; $0.6 \div 1.0 \mathrm{~g} \mathrm{d.w}$. shoot $^{-1} \mathrm{y}^{-1}$, [45]). The annual leaf production calculated over $\mathrm{m}^{2}$ (Fig. 6) generally decreased in the deepest and off-shore stations of each transect, where the availability of light and resources were reduced compared with the coastal stations [45].

The results of lepidochronological analyses also displayed similar values of the annual leaf production in the last three lepidochronological cycles $(2006,2007,2008)$ and a slight increase over time, suggesting that the meadow is not subjected to important stress or damages.

\section{CONCLUSIONS}

The integrated monitoring approach adopted in the study area was developed through a multidisciplinary investigation including the main ecosystem components, from hydrological variables to biological components. Results of chemical and biological investigations were typical of coastal and unpolluted areas. The low concentrations of TOC and trace metals in surface sediments, together with the high biodiversity of meio- and macrobenthic communities, suggested a good status of health of the coastal marine ecosystem. The P.oceanica, even though characterized by low shoot densities, displayed a slight increase of the annual leaf production in the last three lepidochronological cycles, suggesting a reduced or absent environmental stress on the meadow.

The integrated monitoring approach performed in the present study, if routinely applied, could represent an important tool allowing the understanding and assessment of the health status of marine ecosystems and of their natural resources. It could also enhance and support our understanding and ability to predict the causes and consequences of environmental changes and of the ecosystem response to anthropogenic impact, providing useful informations also for the forecasting of short-term trends and for the development of a long-term monitoring plan regarding the most representative 
variables, devoted to an early warning in case of exceeding or approaching threshold limits.

\section{ACKNOWLEDGEMENTS}

We would thank Mr. Antonio De Roma and Mr. Giuseppe Marasco of Enipower Brindisi for their collaboration and availability. This is contribution no. 143 of the Istituto di Ricerca Gruppo CSA.

\section{REFERENCES}

[1] Short FT, Wyllie-Echeverria S. Natural and human-induced disturbances of seagrasses. Environ Cons 1996; 23: 17-27.

[2] Duarte CM. Marine biodiversity and ecosystem services: an elusive link. J Exp Mar Biol Ecol 2000; 250: 117-31.

[3] Jeudy De Grissac A. Impact des aménagements littoraux: installations portuaires, plages artificielles, quelques exemples provençaux. Centre National pour l'Exploitation des Océans, Marseille 1979; p. 46.

[4] Boudouresque C F, Meinesz A. Découverte de l'hervier de Posidonie. Cahier Parc National Port-Cross 1982; 4: 1-79.

[5] Marbà N, Duarte CM, Cebrian J, Gallegos ME, Olesen B, Sand-Jensen K. Growth and population dynamics of Posidonia oceanica on the Spanish Mediterranean coast: elucidating seagrass decline. Mar Ecol Prog Ser 1996; 137: 203-13.

[6] Sánchez-Lizaso JL, Guillén JE, Ramos AA. The regression of Posidonia oceanica meadows in El Campello (Spain). Rapports et Procès-Verbaux des Réunions de la Commission Internationale pour l'Exploration Scientifique de la Méditerrané 1990; 32: 7.

[7] Delgado O, Ruiz JM., Pérez M, Romero J, Ballesteros E. Effects of fish farming on seagrass (Posidonia oceanica) in a Mediterranean bay: seagrass decline after organic loading cessation. Oceanol Acta 1999; 22: 109-17.

[8] Ruiz JM, Romero J. Effects of disturbance caused by coastal constructions on spatial structure, growth, dynamics and photosynthesis of the seagrass Posidonia oceanica. Mar Poll Bull 2003; 46: 1523-33.

[9] Fernández-Torquemada Y, Sánchez-Lizaso JL, González-Correa JM. Preliminary results of the monitoring of the brine discharge produced by the SWRO desalination plant of Alicante (SE Spain). Desalin 2005; 182: 395-402.

[10] González-Correa JM, Fernández-Torquemada Y, Sánchez-Lizaso JL. Long-term effect of beach replenishment on natural recovery of shallow Posidonia oceanica meadows. Estuar Coast Shelf Sci 2008; 76: 834-44.

[11] Pergent-Martini C, Pergent G. Marine phanerogams as a tool in the evaluation of marine trace-metal contamination: an example from the Mediterranean. Int J Environ Pollut 2000; 13: 126-47.

[12] Casazza G, Lopez Royo C, Silvestri C. Seagrasses as key coastal ecosystems: an overview of the recent EU WFD requirements and current applications. Biol Mar Med 2006; 13: 189-93.

[13] Dauer DM. Biological criteria, environmental health and estuarine macrobenthic community structure. Mar Poll Bull 1993; 26 (Pt 5): 249-57.

[14] Cicero AM, Di Girolamo I, Eds. Metodologie Analitiche di Riferimento del Programma di Riferimento per il controllo dell'ambiente marino costiero (triennio 2001-2003). Ministero dell'Ambiente e della Tutela del Territorio, ICRAM, Roma 2001.

[15] Fofonoff NP, Millard RC Jr. Algorithms for computation of fundamental properties of seawater. Division of Marine Science, UNESCO. Technical Papers in Marine Science 1983; 44: 1-53.

[16] Danovaro R, Gambi C, Manini E, Fabiano M. Meiofauna response to a dynamic river input. Mar Biol 2000; 137: 359-70.

[17] Drew EA. Botany. Underwater Science. An introduction to experiments by divers. In Woods JD, Lithgoe JN Eds. Academic Press: London 1971; pp. 175-233.

[18] Paparella P, Martino G. Variazioni spazio-temporali delle condizioni trofiche delle acque costiere pugliesi dal fiume Candelabro a Brindisi (1998-1999). Thalassia Salentina 2008; 53-66.

[19] Kennedy AD, Jacoby CA. Biological indicators of marine environmental health: meiofauna - a neglected benthic component? Environ Monit Assess 1999; 54: 47-68.
[20] Pergent G, Pergent-Martini C, Boudouresque CF. Utilisation de l'herbier a Posidonia oceanica comme indicateur biologique de la qualité du milieu littoral en Méditerranée: état des connaissances. Mesogée 1995; 54: 3-27.

[21] Pergent G, Pergent-Martini C. Leaf renewal cycle and primary production of Posidonia oceanica in the Bay of Lacco Ameno (Ischia, Italy) using lepidochronological analysis. Aquat Bot 1991; 42: 49-66.

[22] Reichenberg F, Mayers P. Two complementary sides of bioavailability: accessibility and chemical activity of organic contaminants in sediments and soils. Environ Toxicol Chem 2006; 25: 1239-45.

[23] Campanella L, Contib ME, Cubaddac F, Sucapane C. Trace metals in seagrass, algae and molluscs from an uncontaminated area in the Mediterranean. Environ Pollut 2001; 111: 117-26.

[24] Capiomont A, Piazzi L, Pergent G. Seasonal variations of total mercury in foliar tissues of Posidonia oceanica. J Mar Biol Assess UK 2000; 80: 1119-23.

[25] Maserti BE, Ferrara R, Paterno P. Posidonia as an indicator of mercury contamination. Mar Pollut Bull 1988; 19: 381-2.

[26] Pergent-Martini C. Posidonia oceanica: a biological indicator of past and present mercury contamination in the Mediterranean sea. Mar Environ Res 1998; 45: 101-11.

[27] Warnau M, Fowler SW, Teyssie JL. Biokinetics of selected heavy metals and radionuclides in two marine macrophytes: the seagrass Posidonia oceanica and the alga Caulerpa taxifolia. Mar Environ Res 1996; 41: 343-62.

[28] Lafabrie C, Pergent-Martini C, Pergent G. Metal contamination of Posidonia oceanica meadows along the Corsican coastline (Mediterranean). Environ Pollut 2008; 151: 262-8.

[29] Maleaa P, Haritonidisa S, Kevrekidisb T. Seasonal and local variations of metal concentrations in the seagrass Posidonia oceanica (L.) Delile in the Antikyra Gulf, Greece. Sci Total Environ 1994; 153: 225-35.

[30] Catsiki VA, Panayotidis P. Copper, chromium and nickel in tissues of the Mediterranean seagrasses Posidonia oceanica \& Cymodocea nodosa (Potamogetonaceae) from Greek coastal areas. Chemosphere. 1993; 26: 963-78

[31] Schlacher-Hoenlinger MA, Schlacher TA. Accumulation, contamination, and seasonal variability of trace metals in the coastal zone patterns in a seagrass meadow from the Mediterranean. Mar Biol 1998; 131: 401-10.

[32] Lyngby JE, Brix H. Seasonal and environmental variation in cadmium, copper, lead and zinc concentrations in eelgrass (Zostera marina L.) in the Limfjord, Denmark. Aquat Bot 1982; 14: 59-74.

[33] Higgins RP, Thiel H. Introduction to the study of meiofauna. Smithsonian Institution Press: Washington DC. 1988.

[34] La Rosa T, Mirtoa S, Mazzola A, Danovaro R. Differential responses of benthic microbes and meiofauna to fish-farm disturbance in coastal sediments. Environ Pollut 2001; 112: 427-34.

[35] Coull BC, Bell SS. Perspectives of marine meiofaunal ecology. In: Livingston RJ, Ed. Ecological processes in coastal and marine ecosystems. New York: Plenum Press 1979; pp. 189-216.

[36] Hennig HFKO, Eagle GA, Fielder L, et al. Ratio and population density of psammolittoral meiofauna as a perturbation indicator of sandy beaches in South Africa. Environ Monit Assess 1983; 3: 4560.

[37] Augier H. Inventaire et classification des biocénoses marines benthiques de la Méditerranée. Publication du Conseil de l' Europe, Coll. Sauvegarde de la Nature 1982, pp. 25-59.

[38] Lastra M, de La Huz R, Sánchez-Mata AG et al. Ecology of exposed sandy beaches in northern Spain: Environmental factors controlling macrofauna communities. J Sea Res 2006; 55: 128- 40.

[39] Simonini R, Ansaloni I, Bonvicini Pagliaia AM, et al. The effects of sand extraction on the macrobenthos of a relict sands area (northern Adriatic Sea): results 12 months post-extraction. Mar Poll Bull 2005; 50: 768-77.

[40] Simboura N, Zenetos A. Benthic indicators to use in ecological quality classification of Mediterranean soft bottoms marine ecosystems, including a new biotic index. Medit Mar Sci 2002; 3: 77-111.

[41] Shenková J, Helešic J. Habitat preferences of aquatic Oligochaeta (Annelida) in the Rokttná River, Czech Republic- a small highland stream. Hydrobiol 2006; 564 (1): 117-26.

[42] Sghaier YR, Zakhama-Sraieb R, Charfi-Cheikhrohua F. Status of Posidonia oceanica meadows along the eastern coast of Tunisia. In: Gambi MC, Borg JA, Buia MC et al., Eds. Mediterranean Sea- 
grass workshop, Malta, 29 May-4 June 2006. Biol Mar Medit 2006; 13: 85-91.

[43] Guidetti P. Differences among fish assemblages associated with nearshore Posidonia oceanica seagrass beds, rocky-algal reefs and unvegetated sand habitats in the Adriatic Sea. Estuar Coast Shelf Sci 2000; 50: 515-29.

[44] Giraud G. Essai de classement des herbiers de Posidonia oceanica (Linné) Delile. Bot Mar 1977; 20: 487-91.

[45] Olesen B, Enríquez S, Duarte CM, Sand-Jensen K.. Depthacclimation of photosynthesis, morphology and demography of Posidonia oceanica and Cymodocea nodosa in the Spanish Mediterranean Sea. Mar Ecol Prog Ser 2002; 236: 89-97.
[46] Hemminga MA, Duarte CM. Seagrass ecology. Cambridge: Cambridge University Press 1994; p. 298.

[47] Larkum WD, Orth RJ, Duarte CM, Eds. Segrasses: biology, ecology and conservation. Dordrecht (The Netherlands): Springer. 2006.

[48] Alcoverro T, Duarte CM, Romero J. Annual growth dynamics of Posidonia oceanica. Contribution of large scale versus local factors to seasonality. Mar Ecol Prog Ser 1995; 120: 203-10.

[49] Pergent G, Romero J, Pergent-Martini C, Mateo MJ, Boudouresque CF. Primary production, stocks and fluxes in the Mediterranean seagrass Posidonia oceanica. Mar Ecol Prog Ser 1994; 106: 13946.

(C) Matteucci et al.: Licensee Bentham Open.

This is an open access article licensed under the terms of the Creative Commons Attribution Non-Commercial License (http://creativecommons.org/licenses/ by-nc/3.0/) which permits unrestricted, non-commercial use, distribution and reproduction in any medium, provided the work is properly cited. 